Yehudah B. Cohn

\title{
Reading Material Features of Qumran Tefillin and Mezuzot
}

For fifty years or so, after the Qumran tefillin and mezuzot first came to light, scholarly focus centered on the biblical texts they contained, and on the relation of these artifacts to practices later discussed by post-destruction rabbis. ${ }^{1}$ More recent works by Adler and Cohn have treated material features independently of the rabbinic corpus, alongside textual ones, ${ }^{2}$ and here I will "reread" material features. To put it slightly differently, my goal in this article is to highlight the extent to which material considerations have informed the analysis of the Qumran tefillin and mezuzot-including instances where the material record shows less than has sometimes been claimed. ${ }^{3}$

\section{Material Considerations in Identifying the Tefillin and Mezuzot}

The items concerned consisted of some forty-five leather slips, preserved in fragmentary form, inscribed with excerpted biblical text. ${ }^{4}$ In addition there were around twenty-five tefillin housings, only two of which contained decipherable written content when found. ${ }^{5}$

1 References for the official publications of the texts are as follows: Barthélemy 1955, with plate XIV; Kuhn 1957 (these four texts were republished in DJD 6 by Milik 1962 [see below] together with the rest of the Cave 4 tefillin. Milik had identified further fragments as being from the same slips as those published by Kuhn, and also corrected some of the latter's readings. The four slips concerned have recently been republished in Busa 2015); Baillet 1962 (see also vol. $3^{\star \star}$ [Planches], XXXII-XXXIV); Yadin 1970 (Yadin's readings were subsequently corrected slightly in Baillet 1970); Milik 1977, with plates VII-XXVII. Official publications of the tefillin housings are Harding 1955, with plate 1.5-7; de Vaux 1962, 31 (see also vol. $3^{\star \star}$ [Planches], VIII.5-6); Milik 1962 (see also vol.3*^ [Planches], XXXVIII.8; Yadin 1970; Milik 1977 (see also plate VI.1-13).

2 Cohn 2008, 55-79, 87-99; Adler 2017. For harmonization of the finds with rabbinic literature see in particular Yadin 1970; Rothstein 1992; Nakman 2004.

3 I will not however rehearse all the material characteristics of the findings, which can be found in the original publications, and are synthesized in the works by Adler, Cohn and Rothstein referenced in the previous footnote. Rothstein's work included discussion of scribal characteristics that had not been considered relevant for investigation by the original publishers.

4 The final volume of the Discoveries in the Judaean Desert series lists only thirty-three such tefillin and mezuzah texts from Qumran. See Tov 2002. The DJD 39 total is, however, a little misleading. It is due to some sets of multiple slips being treated as single items by their publishers, while others were not, as well as to some-but not all-indecipherable slips being ignored.

5 The word "found" is used loosely when referring to slips and housings, as many were not found in situ by archaeologists. In fact the Qumran provenance of many tefillin and mezuzot was identified 
The housings, when closed, took the exterior form of a flattish rectangular leather pouch with one or more small protrusions; these were due to cells, inside which the slips had been placed. Although the housings were no longer stitched shut, as the sewing medium had disintegrated over their two millennia existence, the original thread holes were still visible. Fourteen of the housings contained four cells each for holding texts, two had three cells-quite possibly because they were incomplete fourcell types-, and the remainder had one cell each. Their identification as tefillin housings is assured, because five were discovered with their parchment contents still inside-three in Qumran Cave 4, one in Cave 5, and one that was purchased. While none of the one-cell types happened to contain parchment, both three-cell exemplars and three of the four-cell ones were found with parchment slips inside. Out of these, one three-cell and one four-cell type each contained three decipherable slips; the contents of the other three housings that still held parchment were too distressed to be unrolled. ${ }^{6}$

It is noteworthy that the first tefillin slips to be published were not found inside housings. Accordingly, their identification as part of a worn object was largely based on the resemblance of their contents to rabbinic tefillin texts. Even without such data, however, the very fact of an excerpted set of texts that mentioned tying would have been suggestive. Subsequently, 4QPhyl D, E, F and XQPhyl 1-3, which had been found inside their original housings, were published, so that the identification of all the tefillin texts came to rest on even more certain footing. Their characteristic script, combined with the overall textual similarity of the many exemplars to one another, reinforce the view that other slips containing verses from the same passages originated in tefillin.

Mezuzot are another matter. No mezuzah cases were found, and it is possible that mezuzot were anyway stuffed into interstitial spaces in doorframes without a covering. Altogether eight mezuzot were however identified, and distinguished from tefillin entirely on the basis of material characteristics-the distinctiveness of the way they were written, and the thickness and size of the slips concerned. Milik and Baillet, the two scholars who discussed mezuzot, distinguish them from tefillin in mentioning

- the superior quality of their calligraphy,

- paleographic development, to be contrasted with a uniform tefillin script,

- the general presence of intervals between words,

as such by sellers, or their representatives, who had in effect looted the objects, and who in certain instances demonstrably provided false information about their finds. Having said that, I follow other scholars who take their Qumran identification seriously, although I cannot deny that "finding” may in some instances have taken place elsewhere in the Judean desert. Of the two tefillin housings just mentioned here, the one published in Yadin 1970 was purchased, and included an indecipherable slip that was determined by Yadin not to have been original to the housing.

6 Using recent technological advances, Yonatan Adler hopes in the near future to publish several slips that had previously been considered indecipherable. 
- margins on both left and right,

- extensions of last letters on some lines as a way of filling out blank space,

- somewhat greater letter size,

- much greater intervals between lines, and

- thicker skin than used for tefillin.

The absence of these features in tefillin was likely dictated by the tiny size of the tefillin slips, and of the housings into which they fit. This size in turn may have been related to the need to wear them conveniently, particularly if they were worn throughout the day. Mezuzot, on the other hand, might have been larger; although as no mezuzah cases were identified one cannot be certain. Scribes may well have been unconcerned about the aesthetic features of tefillin slips, which anyway could not be read once placed in their housings that were sewn shut.

There was, in any event, no attempt by researchers to discriminate between the two artifacts based on differences between the scriptural passages observed. It bears mentioning that in the absence of rabbinic literature, one would likely have imagined any practice evolving from Deut 6:9 and 11:20 as associated with writing on doorposts and gates, rather than on leather slips that were placed on doorposts and gates. Additionally, the rabbinic record does not allow for Exodus verses in mezuzot, as contained by two of the Qumran mezuzot, so that viewing some of these slips as mezuzot entails not merely harmonization with later practice but selective harmonization at that. It therefore seems possible that the so-called mezuzot are merely large tefillin, worn in larger housings than those that were found. (Conversely, if Exodus verses were indeed considered suitable as mezuzah contents then some of the slips identified as tefillin might perhaps have been mezuzot.)

One set of slips, forming a wad, demonstrates the existence of a larger type of tefillin housing, although none of these were found. ${ }^{7}$ Additionally, this set demonstrates that several slips might have been inserted into a single compartment, as a single wad of slips could hardly have been split up over several cells. In fact, many more such wads were traced to Cave $11 ;^{8}$ they share many characteristics with tefillin-thin and brittle, folded parchment, traces of thread marks where skin had been wrapped, tiny script, and hardly any space between the lines-but are quite unlike other Qumran manuscripts. All Cave 11 wads were indecipherable. ${ }^{9}$

In the light of later rabbinic texts, the four-cell exemplars were identified as belonging to head tefillin, and the one-cell type as belonging to arm tefillin. ${ }^{10}$

\footnotetext{
7 Barthélemy 1955.

8 11QUnidentified Wads, cf. García Martínez/Tigchelaar/van der Woude (eds.) 1998, 445-446.

9 See fn. 6. Adler is hoping to decipher the Cave 11 wads too.

10 This basis for classifying the objects was not always articulated by the publishers, but no better rationale for the identification is evident. In fact the original Hebrew title of Yadin's publication was "Head-tefillin from Qumran", and was changed for the English version.
} 
Accordingly, the taxonomy rests entirely on the presumption of a conservative nature to tefillin practice. It is naturally impossible to know whether that presumption is valid, but the contained texts, when compared to the descriptions of rabbinic tefillin, may suggest otherwise.

Along related lines, it is also tempting to imagine that the one-cell and four-cell types represent the two distinct elements of a single practice. There is however, scant basis for presuming as much. Indeed, the different types may simply reflect alternative understandings of how the practice was to be observed, with individual practitioners wearing two housings of the same kind, or conceivably wearing only one. The variety of practice implied by the findings is anyway quite striking, and one can readily view it as having been rather haphazard.

\section{Is a Proto-Halakhah of Tefillin and Mezuzah Exhibited at Qumran?}

Few of the tefillin or mezuzot, if any, conformed to rabbinic halakhah, if only by virtue of textual differences-the best examples are those that included the Decalogue, which the rabbinic versions do not. Efforts have been made to argue, nevertheless, that they reflect a proto-halakhah, and to discount the textual diversity exhibited, and even in the absence of any such argument the idea of a proto-halakhah has simply been assumed by some scholars. Instead, I would suggest, material diversity needs to be given equal weight in determining the likelihood of a proto-halakhah. There follows a listing of diversity exhibited by material features of the findings, among which I include mise-en-page.

1. In eight of the twelve slips containing text from both Deuteronomy and Exodus, verses from the former book preceded any from the latter; this order is reversed in the case of the other four (the slips were essentially written in a single column, and here I am referring to their top-to-bottom order).

2. Vacats between individual text passages were used sometimes but not consistently.

3. There is some evidence of word separation, but in most of the tefillin exemplars words are not separated.

4. There is diversity with regard to interlinear additions, and to splitting up words at the end of lines.

5. In one instance (8QPhyl 1) two biblical pericopes were written in a kind of multicolumn format. Specifically, Deut 11:13-21 was written in the shape of a backwards "L". Each side of the "L" contained multiple lines of text, and Deut 6:4-9 was inscribed inside the space bounded by these two sides.

6. 4QPhyl J has an unusual layout, which will be discussed separately below as a significant anomaly for understanding the development of the practice. 
7. Some slips were inscribed on both recto and verso, while others were not.

8. Some slips were written on the hair side of the skin, others on the inside.

9. 1QPhyl was found in a single wad, too large for any of the housings observed.

10. There were additions/omissions throughout the corpus of slips, and some will be discussed separately below as anomalies whose significance is particularly important for understanding the development of the practices.

11. In some of the multi-compartment tefillin housings the four compartments were fanned out, due to incisions between them, but in many others that was not the case.

The degree of diversity described above suggests that looking for a proto-halakhah is anachronistic. If indeed there were no fixed set of rules, then it seems that the slips and housings are to be viewed as representing popular practices.

\section{Are the Qumran Tefillin and Mezuzot Sectarian?}

The existence of distinct practices among Second Temple era sects is known from the writings of Josephus and others, and sectarian texts, most commonly identified with the Essenes, were found at Qumran. With all tefillin and mezuzah finds from the Second Temple period traced to Qumran, one thus needs to consider the possibility that these represent sectarian practice.

It is first to be noted that nothing in the Qumran community's literature suggests these rituals, much less their being specific to its members. Interestingly, Norman Golb has observed that Qumran sectarians, authors of the Manual of Discipline, are not good candidates for having understood the relevant verses literally, because they "evince the very opposite tendency to interpret the literal injunctions of the Pentateuch as metaphors". ${ }^{11}$ In addition, it was argued above that these objects do not exhibit a proto-halakhah of any kind, so that the onus of proof seems to rest with those who have claimed-to the contrary-that they actually demonstrate sectarian difference with respect to correct practice. ${ }^{12}$

11 Golb 1995, 103-104.

12 The first to attempt a classification along sectarian lines was Milik, who identified two types of Qumran tefillin and mezuzot (Milik 1977, 46-47). Those close to rabbinic practice in textual content, or at any rate not clearly deviating from it, he categorized as Pharisaic type. Others were branded as Essene type. Milik's labels rested on the idea that rabbinic practice was presumably Pharisaic in origin and that non-rabbinic Qumran exemplars were presumably Essene in origin. This position has been progressively undermined, with Nakman arguing that none of the tefillin were sectarian, and Yonatan Adler claiming that Milik's classification does not serve to discriminate between those that were sectarian and those that were not. See Nakman 2004; Adler 2007. 
Emanuel Tov has produced a monumental work on scribal practices at Qumran, in which he isolated the scribal practices exhibited by the sectarian documents found there. ${ }^{13}$ Inter alia he was thus able to argue that some of the Qumran tefillin and mezu$z o t$ were sectarian, while others were not. Since Tov's book, there has been considerable debate about these scribal practices. Adler-taking issue with other elements of Tov's argument-has whittled down the so-called Pharisaic tefillin slips, namely those that do not show sectarian scribal characteristics, to 4QPhyl D, E, F and 8QPhyl I-the only ones, in this conception, that are not to be considered unique to the sectarian Qumran community. ${ }^{14}$ Even that position looks dubious, if only because the identification rests on readings that are at variance with those of their publishers-and there anyway seems to have been insufficient scribal practice data to make any determination regarding 4QPhyl D and E. In addition, Tov's work has been critiqued more generally in arguing for a Qumran scribal practice, ${ }^{15}$ and he himself has modified some of his earlier views. ${ }^{16}$ At this point there seems to be no good evidence for sectarian difference with respect to early tefillin and mezuzah practice.

\section{Are the Qumran Tefillin and Mezuzot to be Viewed as Amulets?}

I will begin this section with evidence that I consider important to the question, discussing how others have interpreted it, and will then provide my own analysis.

\section{Ommissions and Layout}

As mentioned above, in the discussion of diversity, there were differing layouts and omissions noted. Relevant anomalies here are the presence of certain particular omissions, and the unusual layout of one of the slips. In talking of omissions I am referring to those peculiar to the corpus of mezuzot and tefillin slips, when considered in relation to other important textual witnesses. While one can never be certain that an omission was intentional, a clustering of omissions around particular verses or notions is suggestive and warrants investigation. There is no attested Urtext to explain these omissions, and I view them as best considered alongside material features rather than literary ones.

13 Tov 2004.

14 Adler 2007; for his disagreement with Tov 2004, see fn. 33 and 44.

15 See in particular Tigchelaar 2010.

16 Most recently with respect to tefillin in Tov 2017. 


\section{List of Omissions}

- 4QPhyl A: within Deut 5:32 (starting after ushemartem) to the end of 6:1

- 4QPhyl B: within Deut 5:31 (starting after telammedem) to the end of 6:1

- 4QPhyl H: ulema'an ya'arikhun yamekha in Deut 6:2

- 4QPhyl J: within Deut 5:32 (starting after lo) to 6:2 (ending before asher)

- 8QPhyl II: kol yeme hayyekha ulema'an ya'arikhun yamekha in Deut 6:2, and asher yitav lekha va'asher tirbun me'od in Deut 6:3

- 8QPhyl IV: Deut 11:8 (replaced by lema'an tihyu veyitbu yamim)

- 4QMez C: within Deut 5:32 (starting after tsivvah) to Deut 5:33 (ending before veha'arakhtem)

All omissions in the above list cluster around verses related to length of days. In Deut 6:2, in 4QPhyl H and 8QPhyl II, the omitted words are shown in the list. In 8QPhyl IV, Deut 11:8 is omitted; it specifies fulfillment of all the commandments as a condition for entering and possessing the land as well as achieving length of days on it-according to the next verse, which is a parallel to Deut 11:21. The range of words for the other omissions, in 4QPhyl A, B, and J, and 4QMez C, all include a connection between precise or complete observance of the commandments, at Deut 5:32, 5:33, and 6:2; and length of days, at 5:33 and 6:2.

While Milik had suggested homeoteleuton as a possible cause for the omitted text, in the case of 4QPhyl B as well as 4QMez C, Alexander Rofé subsequently took issue with the possibility. The latter proceeded to provide an explanation for the lacunae in $4 \mathrm{QPhyl} \mathrm{A}, \mathrm{B}$, and J, to the effect that they resulted from an otherwise unattested Urtext-while acknowledging that this did not fully explain the missing text in 4QPhyl J. ${ }^{17}$ His basis for preferring this seemingly drastic suggestion to an intentional omission rested on a presumption as to the unlikelihood of the latter in a tefillin or mezuzah parchment. This was in turn based on the idea of a halakhah of correct practice, whose unlikelihood has already been discussed; indeed, there is positive evidence that some scribes were not concerned with textual fidelity, as exhibited by harmonization between the Deuteronomy and Exodus Decalogues, which may well have been due to scribes writing from memory.

A diametrically opposite suggestion has also been made, to the effect that text was abbreviated in Deut 5:32-6:2 because scribes found their content to be repetitive. ${ }^{18}$ This seems implausible to me; tefillin and mezuzah scribes look to have sought out innerbiblical repetition rather than avoided it.

17 Rofé 1985, 9-13.

18 Brooke 2003, 64-65. 


\section{Unusual Layout}

A final piece of material evidence that calls for interpretation is the uniquely strange layout on the verso of 4QPhyl J. ${ }^{19}$ The first verse in biblical sequence, Deut 5:24, starts in the middle of the parchment slip and is followed by vv. 5:25-28. Text from Deut 5:29-32 is upside down at the top of the slip and is accordingly out of sequence, and sandwiched in between it and Deut 5:24 is part of Deut 6:2 together with 6:3, which are written the right way up.

In K. G. Kuhn's initial publication of 4QPhyl J, which preceded DJD's by twenty years, the former attempted to explain its layout with the suggestion that the scribe twice inverted the parchment when running out of space. This implies that on two occasions the space required for the desired text was severely misgauged. I will now provide my own view of the phenomena highlighted in this section and the previous one.

I have argued elsewhere that the practices of tefillin and mezuzah both arose from a very literalist interpretation of Deuteronomy 11:18, 20 and $21 .^{20}$

You are to place these my words upon your heart and upon your soul, and you shall tie them as a sign on your hand and they shall be as totafot between your eyes, [...] and you shall write them on the doorframes of your houses and within your gates,

So that your days and the days of your children may be many in the land that YHWH swore to give your ancestors, as many as the days that the heavens are above the earth.

My suggestion, in other words, is that tefillin and mezuzah were seen as bringing length of days to their practitioners, and would thus have served as protection against premature death, or-on a more positive note-as an amuletic prayer for length of days. I have left the word totafot untranslated because one cannot be at all sure of its meaning. The Septuagint does not seem familiar with the rare word, rendering it by the adjective "immovable"-or in some manuscripts "movable"-and it seems quite likely that its authors were quite unaware of the practices known to us. The literalism involved in interpreting the bible here to be referring to actual rituals, rather than metaphors of some kind, would be consonant with what we know about the Maccabean period, as would the invention of tradition entailed in developing such rituals. If so the Qumran tefillin and mezuzot are not merely the earliest evidence for the practice, but may in fact reflect the early history of its adoption.

Requirements for achieving length of days on the land, as detailed in Deut 5:32-6:2 and 11:8-9, included fulfillment of all that had been commanded (5:33; 6:2; and 11:8), and precise observance of the commandments (5:32). These prerequisites would, of course, have been far more onerous than the rather simple expedient of wearing an

19 For a more general discussion of the Qumran tefillin opisthographs see Brooke 2011.

20 Cohn 2008, 87-99. 
amulet or placing one outside one's home. If tefillin and mezuzot practices were supposed to achieve the same outcome-i. e. length of days on the land, as promised by Deut 11:21-then some scribes might have felt it best to omit the other verses on this subject so as to avoid highlighting to God-or perhaps to practitioners-the stringent obligations they included. Indeed, it is worth noting that other scribes avoided these problematic verses altogether, in beginning one of their Deuteronomy passages at 6:4, and the other at 11:13-just as rabbinic mezuzot and tefillin do.

In this context the upside-down writing of Deut 5:29-32 in 4QPhyl J is also particularly striking, for in 5:29 observance of all God's commandments (kol mitsvotay) is a precondition for eternal good befalling the people and their children, and 5:32 talks of unwavering adherence to God's command (lo tasuru yamin usmol). The right-side-up writing resumes in the second part of 6:2, with its mention of long life; the first part of that verse, which calls for observance of all the laws and commandments (kol huqqotav umitsvotav), is missing.

The sympathetic or "persuasively analogical" function of abnormal writing has been dated to a fourth century BCE Attic curse, which was written backwards-from right to left-with the explicit wish that this form of writing have a concomitant effect. ${ }^{21}$ The upside-down writing in 4QPhyl J, as well indeed as the omissions that were discussed earlier, can thus be seen as representing a wish for inversion/omission of the relevant conditions for achieving long life-practitioners/scribes may have understandably preferred to view these conditions as limited to wearing the objects, or placing them on their doorposts. The amulet hypothesis can thus explain the omissions in the list above, as well as the strange layout of 4QPhyl J.

\section{Bibliography}

Adler, Yonatan (2007), “Identifying Sectarian Characteristics in the Phylacteries from Qumran”, in: Revue de Qumran 23 (1), 79-92.

Adler, Yonatan (2017), “The Distribution of Tefillin Finds among the Judean Desert Caves”, in: Marcello Fidanzio (ed.), The Caves of Qumran (Studies on the Texts of the Desert of Judah 118), Leiden, 161-173.

Baillet, Maurice (1962), “Grotte 8: Phylactère, Mezouza”, in: M. Maurice Baillet, Jozef T. Milik and Roland de Vaux (eds.), Les 'Petites Grottes' de Qumrân (Discoveries in the Judaean Desert 3), Oxford, 149-161.

Baillet, Maurice (1970), “Nouveaux phylactères de Qumran (XQPhyl 1-4). A propos d'une édition récente", in: Revue de Qumran 7 (27), 403-415.

Barthélemy, Dominique (1955), “Textes Bibliques, Phylactére”, in: Dominique Barthélemy and Jozef T. Milik (eds.), Qumran Cave I (Discoveries in the Judaean Desert 1), Oxford, 72-76.

21 "Just as these words are cold and backwards (lit. eparistera-written right to left), so too may the words of Krates be cold and backwards." See Faraone 1991, 6-10; Ogden 1999, 29-30. The expression "persuasively analogical" is owed to Tambiah 1973, 211-213. 
Brooke, George J. (2003), "Deuteronomy 5-6 in the Phylacteries from Qumran Cave 4", in: Shalom M. Paul et al. (eds.), Emanuel: Studies in Hebrew Bible, Septuagint, and Dead Sea Scrolls in Honor of Emanuel Tov (Supplements to Vetus Testamentum 94), Leiden, 57-70.

Brooke, George J. (2011), "Between Scroll and Codex? Reconsidering the Qumran Opisthographs," in: ed. James K. Aitken, Katharine J. Dell and Brian A. Mastin et al. (eds.), On Stone and Scroll: Studies in Honor of Graham I. Davies (Beihefte zur Zeitschrift für die alttestamentliche Wissenschaft 420), Berlin, 123-138.

Busa, Anna (2015), Die Phylakterien von Qumran (4Q128.129.135.137) aus der Heidelberger Papyrussammlung (Veröffentlichungen aus der Heidelberger Papyrus-Sammlung 15), Heidelberg.

Cohn, Yehudah B. (2008), Tangled Up in Text: Tefillin and the Ancient World (Brown Judaic Studies 351), Providence.

de Vaux, Roland (1962), “Archéologie: les grottes $7 Q$ à 10Q”, in: M. Maurice Baillet, Jozef T. Milik, and Roland de Vaux (eds.), Les 'Petites Grottes' de Qumrân (Discoveries in the Judaean Desert 3), Oxford, 27-31.

Faraone, Christopher A. (1991), "The Agonistic Context of Early Greek Binding Spells", in: Christopher A. Faraone and Dirk Obbink (eds.), Magika Hiera: Ancient Greek Magic and Religion, New York, 3-32.

García Martínez, Florentino/Tigchelaar. Eibert J. C./van der Woude, Adam S. (eds.) (1998), Qumran Cave 11 (Discoveries in the Judaean Desert 23), Oxford.

Golb, Norman (1995), Who Wrote the Dead Sea Scrolls?, New York.

Harding, Lankester G. (1955), “The Archaeological Finds: Introductory. The Discovery, the Excavation, Minor Finds”, in: Dominique Barthélemy and Jozef T. Milik (eds.), Qumran Cave I (Discoveries in the Judaean Desert 1), Oxford, 3-7.

Kuhn, Karl Georg (1957), Phylakterien aus Höhle 4 von Qumran (Abhandlungen der Heidelberger Akademie der Wissenschaften, Philosophisch-Historische Klasse 1957,1), Heidelberg.

Milik, Józef T. (1962), “Textes de la grotte 5Q: Phylactère”, in: M. Maurice Baillet, Jozef T. Milik, and Roland de Vaux (eds.), Les 'Petites Grottes' de Qumrân (Discoveries in the Judaean Desert 3), Oxford, 178.

Milik, Józef T. (1977), “Tefillin, Mezuzot et Targums”, in: Józef T. Milik (ed.), Qumrân Grotte 4. Il: Tefillin, Mezuzot et Targums (4Q128-4Q157) (Discoveries in the Judaean Desert 6), Oxford, 33-85.

Nakman, David (2004), "The Contents and Order of the Biblical Sections in the Tefillin from Qumran and Rabbinic Halakah", in: Cathedra 112, 19-44 (in Hebrew).

Ogden, Daniel (1999), “Binding Spells: Curse Tablets and Voodoo Dolls in the Greek and Roman Worlds", in: Valerie Flint et al. (eds.), Witchcraft and Magic in Europe 2: Ancient Greece and Rome, London, 3-90.

Rofé Alexander (1985), “Deuteronomy 5:28-6:1, Composition and Text in the Light of Deuteronomic Style and Three Tefillin from Qumran", in: Henoch 7, 1-14.

Rothstein, David (1992), From Bible to Murabba'at: Studies in the Literary, Textual and Scribal Features of Phylacteries and Mezuzot in Ancient Israel and Early Judaism, Ph.D. diss., UCLA, 1992.

Tambiah, Stanley J. (1973), "Form and Meaning of Magical Acts: A Point of View”, in: Robin Horton and Ruth Finnegan (eds.), Modes of Thought; Essays on Thinking in Western and Non-Western Societies, London, 199-229.

Tigchelaar, Eibert J. C. (2010), “Assessing Emanuel Tov's ‘Qumran Scribal Practice”, in: Sarianna Metso et al. (eds.), The Dead Sea Scrolls: Transmission of Traditions and Production of Texts (Studies on the Texts of the Desert of Judah 92), Leiden, 173-208.

Tov, Emanuel (2002), “Categorized List of the 'Biblical Texts': Appendix-Phylacteries (Tefillin) and Mezuzot", in: Emanuel Tov (ed.), Indices and an Introduction to the Discoveries in the Judaean Desert Series (Discoveries in the Judaean Desert 39), Oxford, 182-183. 
Tov, Emanuel (2004), Scribal Practices and Approaches Reflected in the Texts Found in the Judaean Desert (Studies on the Texts of the Desert of Judah 54), Leiden.

Tov, Emanuel (2017), “The Tefillin from the Judean Desert and the Textual Criticism of the Hebrew Bible", in: Ariel Feldman et al. (eds), Is There a Text in This Cave? Studies in the Textuality of the Dead Sea Scrolls in Honour of George J. Brooke (Studies on the Texts of the Desert of Judah 119), Leiden 277-292.

Yadin, Yigael (1969), Tefillin from Qumran (XQPhyl 1-4), Jerusalem. 
